\title{
Satu Dekade Informasi Akuntansi dan Market Venture di Perusahaan Manufaktur Bursa Efek Indonesia
}

\author{
Risa Mardiana ${ }^{1}$, Nurmala Ahmar ${ }^{2}$, Syahril Djaddang ${ }^{3}$ \\ ${ }^{1,3}$ Universitas Pancasila, Jl. Raya Lenteng Agung, Jagakarsa,Jakarta Selatan, 12640. \\ ${ }^{2}$ STIE Perbanas Surabaya, Jalan Nginden Semolo 34-36 Surabaya 60118. Indonesia.
}

I N F O A R T I K E L

JEL Classification:

016

G32

M41

\section{Keywords:}

degree of operating leverage, degree of financial leverage, degree of total leverage, earning.
A $B$ S S T R $R$ A $C$ T

The purpose of this study is prove empirically accounting information affects market venture. This study discusses the accounting information and market ventures in manufacturing companies 2005-2014 Indonesia stock exchange as measured by Degree of Operating Leverage, Degree of Financial Leverage, Degree of Total Leverage, and Earnings. This research is quantitative research with panel data regression with 9.0 eviews to 107 of Manufacturing Indonesia. The study states that the overall absence of influence degree of operating leverage, degree of financial leverage, degree of total leverage and earnings against market venture and the difference results in a year on the degree of operating leverage, degree of financial leverage, degree of total leverage and earnings of the venture market. Research can add a reference material and encourage research accounting on the capital markets, knowledge of information regarding the degree of operating leverage, degree of financial leverage, degree of total leverage and earnings for investment decisions in the capital market, information market venture to investors in a way build institutions and better recording venture market.

\section{A B S T R A K}

Tujuan penelitian ini adalah untuk membuktikan secara empiris tentang Accounting Information mempengaruhi Market Venture. Penelitian ini membahas mengenai informasi akuntansi dan market venture di perusahaan manufaktur bursa efek indonesia 2005-2014 yang diukur dengan Degree of Operating Leverage, Degree of Financial Leverage, Degree of Total Leverage, dan Earnings. Penelitian ini adalah penelitian kuantitatif dengan regresi data panel dengan eviews 9.0 terhadap 107 Perusahaan Manufaktur Indonesia. Hasil penelitian menyatakan bahwa secara keseluruhan tidak terjadinya pengaruh degree of operating leverage, degree of financial leverage, degree of total leverage dan earnings terhadap market venture dan terjadinya perbedaan hasil secara per tahun pada degree of operating leverage, degree of financial leverage, degree of total leverage dan earnings terhadap market venture. Penelitian dapat menambah bahan referensi dan mendorong dilakukannya penelitian-penelitian akuntansi pada pasar modal, pengetahuan informasi mengenai degree of operating leverage, degree of financial leverage, degree of total leverage dan earning bagi keputusan investasi di pasar modal, pemberi informasi market venture kepada investor dengan cara membangun instansi dan pencatatan market venture lebih baik.

*Email Korespondensi: ${ }^{1}$ essay_only@yahoo.com, ${ }^{2}$ ahmarnurmala@gmail.com, 33djaddangsyahril@gmail.com 


\section{Pendahuluan}

Pasar modal merupakan tempat perdagangan efek yang sudah ada dari era pemerintahan penjajahan kolonial Belanda. Pada saat dahulu sampai sekarang pasar modal merupakan tempat investasi bagi para investor. Investasi merupakan kegiatan pembelian yang dilakukan untuk mendapatkan keuntungan di masa depan.

Berdasarkan gambar 1.1, grafik pada tahun 2005 dan 2006 sangat berfluktuatif. Selain itu, tahun 2013 dan 2014 mengalami pergerakan lebih cenderung menurun sedangkan pada tahun 2014 pergerakan lebih cenderung bergerak naik dan turun. Selain itu, keadaan ini membutuhkan informasi akuntansi untuk mengetahui pergerakan grafik tersebut. Informasi akuntansi yang dapat digunakan yaitu degree of operating leverage, degree of financial leverage, degree of total leverage serta earning before interest tax. Informasi akuntansi yang tidak disediakan secara berturut-turut akan membuat para investor mempunyai risk dalam melakukan investasi. Risiko ini dapat dibedakan menjadi dua, yaitu risiko tidak sistematik maupun market venture. Market venture adalah komponen perhitungan valuasi saham dengan metode Capital Assets Pricing Model (CAPM) atau ukuran sensitivitas tingkat pengembalian (return) harga saham tertentu terhadap return pasar dan dengan adanya market venture ini dapat memudahkan investor ritel membaca saham berdasarkan fundamental. Jadi tidak hanya investor besar yang punya fasilitas untuk bertransaksi, tetapi juga investor ritel (SWA, 2013).
Degree of operating leverage memiliki pengaruh positif namun tidak signifikan terhadap market venture karena operating leverage dapat meningkatkan laba sebelum pajak dan bunga atau dikenal earning before interest tax (EBIT), sebaliknya tingkat penjualan rendah akan menurunkan laba sebelum bunga dan pajak sehingga volatilitas laba sebelum bunga dan pajak meningkatkan risiko yang dialami perusahaan dikarenakan rendahnya pendapatan yang diterima (Subhan dan Hamidah: 2015). Selain itu, pengaruh operasi yang rendah dan tercermin penurunan kinerja operasional karena keadaan tenaga kerja di pasar modal efisien menghasilkan signifikan negatif terhadap market venture (Al-Qaisi: 2011). Sementara itu, degree of operating leverage mengalami pengaruh signifikan positif terhadap market venture (Kousis dan Makrominas: 2015). Degree of financial leverage juga tidak mempunyai pengaruh yang signifikan terhadap market venture dikarenakan tingkat sumber dana hutang dalam struktur modal tidak menentukan market venture (Savitri dan Pramudya: 2012). Leverage keuangan tidak berpengaruh kondisi normal atau krisis,dan size dan profitabilitas tidak berpengaruh signifikan (Kartikasari: 2007). Selain itu, perusahaan industri yang sangat bergantung pada pinjaman jangka pendek daripada jangka panjang dalam menentukan struktur keuangan sehingga leverage keuangan berpengaruh signifikan negatif terhadap market venture (Al-Qaisi: 2011). Akan tetapi, degree of financial leverage memiliki pengaruh yang signifikan positif terhadap market venture (Kousis dan Makrominas: 2015). Degree of total

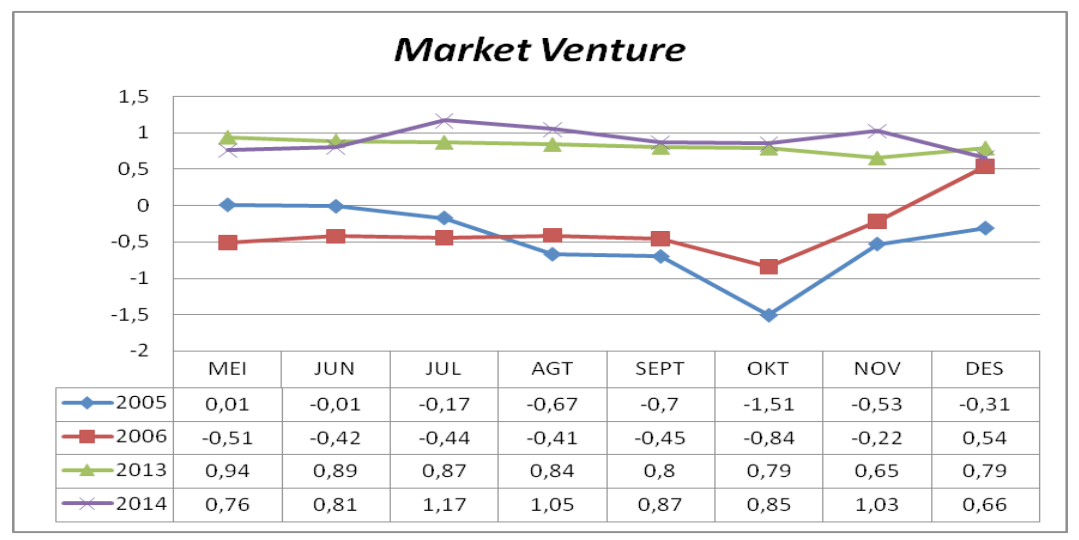

Gambar 1. Perkembangan Market Venture 
leverage untuk sebuah perusahaan dengan pendapatan tahun sebelumnya yang negatif dan pertumbuhan penjualan saat ini tahun dan pendapatan pada saham harga adalah negatif, kemudian degree of total leverage yang diukur sebagai produk derajat operasi dan leverage keuangan memiliki dampak negatif pada market venture akan tetapi sebuah perusahaan dengan pendapatan tahun sebelumnya yang positif dan pertumbuhan penjualan saat ini tahun dan pendapatan pada saham harga adalah positif kemudian degree of total leverage yang diukur sebagai produk derajat operasi dan leverage keuangan memiliki dampak positif pada market venture (Su dan Chiou:2007). Sedangkan earnings merupakan hasil dari kegiatan perusahaan. Ketika menghitung earnings tidak mengurangkan pengeluaran atas peralatan baru tahun walaupun kas sudah dikeluarkan dan mengurangkan penyusutan pada asset yang sebelumnya dibeli walaupun tidak ada kas yang benar-benar dikeluarkan (Brealey, dkk: 2007). Earnings tidak mempengaruhi signifikan terhadap market venture (Subhan dan Hamidah: 2007). Earnings menjadi alternatif positif dalam informasi dari market venture (Jarvela,dkk: 2009), sedangkan earnings juga memiliki pengaruh signifikan negatif terhadap market venture (Hwa Lee dan Wooi Hooy: 2012).

Adapun tujuan penelitian ini adalah untuk membuktikan secara empiris tentang Accounting Information mempengaruhi Market Venture. Lebih rinci dari tujuan penelitian sebagai mengetahui dan menganalisis degree of operating leverage, degree of financial, degree of total leverage, dan earning before interest tax mempengaruhi market venture perusahaan publik di Bursa Efek Indonesia.

\section{Telaah Teori dan Pengembangan Hipotesis}

Clean Surplus Relation Theory mengasumsikan bahwa nilai buku ekuitas sama dengan nilai buku awal perusahaan ditambah dengan laba dikurangi deviden tunai (Chiou dan Su: 2007). Akuntansi memberikan fungsi penting untuk laporan perubahan ekuitas pemilik. Laporan tersebut meliputi neraca dan laporan laba rugi, nilai buku dan laba, dimana nilai buku mengalami perubahan dari pendapatan dikurangi dividen (kontribusi nilai bersih) sehingga dapat diartikan clean surplus relation menekankan bahwa semua perubahan aset/ kewajiban yang tidak terkait dengan deviden harus melewati laporan laba rugi (Ohlson: 1995).

Dengan demikian, kondisi pasar modal yang tidak efisien memerlukan informasi akuntansi melalui laporan laba rugi. Laporan laba rugi yang menghasilkan earning dimana earning dapat berkurang dikarenakan biaya yang tinggi, termasuk biaya operasional dan biaya bunga ditimbulkan hutang.

Market venture ini merupakan perbedaan antara return aktual yang diterima dengan return yang diharapkan. Semakin besar kemungkinan perbedaannya, maka akan semakin besar risiko investasi tersebut. Market venture dari suatu sekuritas atau portofolio yang relatif terhadap risiko pasar dapat diukur dengan beta (Jogiyanto: 2010). Market venture merupakan suatu alat pengukur volatilitas return suatu sekuritas atau return portofolio terhadap return pasar. Beta bernilai 1 menunjukkan bahwa risiko sistematik suatu sekuritas sama dengan risiko pasar dan dalam hal ini risiko pasar adalah gerakan naik turunnya Indeks Harga Saham Gabungan (IHSG). Dengan demikian, IHSG turun sebesar satu persen, maka saham tersebut juga turun sebesar satu persen. Begitupun sebaliknya, IHSG naik sebesar dua persen, maka saham tersebut juga akan naik sebesar dua persen.

Degree of operating leverage atau DOL dapat terjadi dari tindakan sampai sejauh mana biaya tetap dapat digunakan dalam operasi suatu perusahaan sehingga sebagian besar dari total biaya merupakan biaya tetap, maka perusahaan tersebut dikatakan memiliki tingkat leverage operasi (Bringham dan Houston: 2011). Degree of operating leverage dihasilkan dari pembagian perubahan laba sebelum bunga dan pajak dibagi dengan laba sebelum bunga dan pajak dan dibagi dengan perubahan pejualan dibagi dengan penjualan (Chiou dan Su: 2007).

Degree of financial leverage atau DFL 
dihasilkan dari perhitungan pembagaian antara perubahan earning dibagi dengan earning dan dibagi dengan perubahan earning before interest tax dibagi dengan earning before interest tax (Chiou dan Su: 2007). Degree of financial leverage ditimbulkan dari penggunaan sumber dana perusahaan dari hutang yang menyebabkan perusahaan harus menanggung penggunaan hutang setiap tahunnya. Pada umumnya, pendanaan menggunakan hutang akan menigkatkan tingkat pengembalian suatu investasi, tetapi hutang juga meningkatkan risiko para pemilik perusahaan, yaitu pemegang saham biasa (Brigham dan Houston: 2011).

Degree of Total Leverage atau DTL merupakan perhitungan dari kombinasi degree of operating dan degree of financial leverage.

Tabel 1. Matriks Riset Informasi Akuntansi dan Market Venture

\begin{tabular}{|c|c|c|c|}
\hline No. & Variabel & Signifikan & Tidak Signifikan \\
\hline \multirow[t]{8}{*}{1} & DOL & Koussis, et.all (2015) & Subhan, et.all (2015) \\
\hline & & Zare, et, all (2012) & Hwa Lee, et all (2012) \\
\hline & & Houmes, et. all (2012) & \\
\hline & & Al Qaisi (2011) & \\
\hline & & Fidiana (2009) & \\
\hline & & Chiou, et. all (2007) & \\
\hline & & Kartikasari (2007) & \\
\hline & & Jen Li, et. all (1991) & \\
\hline \multirow[t]{9}{*}{2} & DFL & Koussis, et. all (2015) & Kartikasari (2007) \\
\hline & & Ebrahimpour, et. all (2013) & \\
\hline & & Zare, et. all (2012) & \\
\hline & & Alaghi (2011) & \\
\hline & & Al Qaisi (2011) & \\
\hline & & Jarvela, et. all (2009) & \\
\hline & & Fidiana (2009) & \\
\hline & & Chiou, et. all (2007) & \\
\hline & & Jen Li, et. all (1991) & \\
\hline \multirow[t]{8}{*}{3} & DTL & Akbari, et. all (2013) & \\
\hline & & Musavi, et. all (2013) & \\
\hline & & Zare, et. all (2012) & \\
\hline & & Jarvela, et. all (2009) & \\
\hline & & Fidiana (2009) & \\
\hline & & Chiou, et. all (2007) & \\
\hline & & Toms, et. all (2005) & \\
\hline & & Jen Li, et. all (1991) & \\
\hline
\end{tabular}

Selain itu, degree of total leverage menunjukkan perubahan laba per lembar saham terhadap perubahan persen dalam penjualan (Akbari dan Mohammadi: 2013). Kondisi perusahaan mengalami penurunan penjualan maka akan mempengaruhi laba per lembar saham yang akan diperoleh investor.

Earnings merupakan hasil dari kegiatan perusahaan. Earning didapat berdasarkan hasil bersih dari penjualan yang sudah dikurangi beban selama kegiatan perusahaan. Earning juga merupakan komponen untuk perhitungan dari degree of financial leverage, dan degree of total leverage. Earnings merupakan indikator yang baik dan terus-menerus dari risiko bisnis perusahaan dan market venture (Al-Qaisi: 2011). 


\begin{tabular}{|c|c|c|c|}
\hline \multirow[t]{6}{*}{4} & Earnings & Ebrahimpour, et. all (2013) & Subhan, et. all (2015) \\
\hline & & Hwa Lee, et. all (2012) & \\
\hline & & Amorim, et. all (2012) & \\
\hline & & Jarvels, et. all (2009) & \\
\hline & & Fidiana (2009) & \\
\hline & & Toms, et. all (2005) & \\
\hline 5 & Profitabilitas & & Kartikasari (2007) \\
\hline 6 & Size & Subhan, et. all (2015) & Kartikasari (2007) \\
\hline 7 & PBV & Fidiana (2009) & \\
\hline 8 & Trading Volume & Fidiana (2009) & \\
\hline 9 & DPR & Javela, et all (2009) & \\
\hline 10 & Beta on Return & Theriou, et. all (2010) & \\
\hline 11 & CR & Ebrahimpour, et. all (2013) & \\
\hline 12 & Profit Growth & Ebrahimpour, et. all (2013) & \\
\hline
\end{tabular}

Hubungan Degree of Operating Leverage dengan Market Venture

Degree of operating leverage terjadi saat perusahaan mengambil hutang untuk kebutuhan operasi perusahaan. Hal ini menjadikan degree of operating leverage mempunyai pengaruh signifikan terhadap market venture dikarenakan kondisi ekonomi yang baik (Kartikasari: 2007). Selain itu semakin tinggi degree of operating leverage akan menjadikan market venture bertambah tinggi pula (Koussis dan Mikrominas: 2015). Degree of operating leverage mengacu pada laporan laba rugi dikarenakan perhitungan membutuhkan komponen earning before interest tax serta sales. Berdasarkan hal diatas dapat diambil suatu hipotesis yang mengacu pada degree of operating leverag dan market venture. $\mathrm{H}_{1}$ : Degree of Operating Leverage berpengaruh signifikan positif terhadap market venture.

\section{Hubungan Degree of Finacial Leverage dengan Market Venture}

Pendanaan menggunakan hutang akan menigkatkan tingkat pengembalian suatu investasi, tetapi hutang juga meningkatkan risiko para pemilik perusahaan, yaitu pemegang saham biasa (Brigham dan Houston: 2011). Hal ini dibuktikan bahwa degree of financial leverage lebih baik pengaruh signifikan terhadap market venture dibandingkan degree of total leverage (Zare dan Nekounam: 2012). Selain itu semakin tinggi degree of financial leverage akan menjadikan market venture bertambah tinggi pula (Koussis dan Mikrominas: 2015). Degree of financial leverage mengacu pada laporan laba rugi yang memiliki nilai kontribusi bersih pada perusahaan dikarenakan perhitungan membutuhkan komponen earning before interest tax serta earning. Berdasarkan hal diatas dapat diambil suatu hipotesis yang mengacu pada degree of operating leverag dan market venture.

Berdasarkan hal diatas, dapat diambil suatu hipotesis yang mengacu pada degree of financial leverage dan market venture.

$\mathrm{H}_{2}$ : Degree of Financial Leverage berpengaruh signifikan positif terhadap market venture.

\section{Hubungan Degree of Total Leverage dengan Market Venture}

Degree of total leverage merupakan kom-binasi perhitungan dari operating leverage dan financial leverage. Berdasarkan teori CAPM degree of total leverage memiliki pengaruh signifikan positif terhadap market venture (Jarvela,dkk:2009). Selain itu, pengaruh signifikan degree of total leverage terhadap market venture lebih baik daripada degree of operating leverage (Zare dan Nekounam: 2012). Degree of total leverage mengacu pada penggabungan degree of operating leverage dan degree of financial leverage yang mengacu pada laporan laba rugi. Berdasarkan hal diatas dapat diambil suatu hipotesis yang mengacu pada degree of operating leverag dan market venture. 
Berdasarkan hal diatas, dapat diambil suatu hipotesis yang mengacu pada degree of total leverag dan market venture.

$\mathrm{H}_{3}$ : Degree of Total Leverage berpengaruh signifikan positif terhadap market venture.

\section{Hubungan Earnings Before Interest Tax dengan Market Venture}

Earnings merupakan hasil dari kegiatan perusahaan. Ketika menghitung earnings tidak mengurangkan pengeluaran atas peralatan baru tahun walaupun kas sudah dikeluarkan dan mengurangkan penyusutan pada asset yang sebelumnya dibeli walaupun tidak ada kas yang benar-benar dikeluarkan (Brealey, dkk: 2007). Kondisi earnings yang baik akan mempengaruhi kinerja perusahaan saat pengambilan keputusan investasi ataupun pinjaman. Pinjaman yang diperoleh dari earnings yang baik akan mengecilkan market venture. (Hwa Lee dan Wooi Hooy:2012). Informasi akuntansi ini mengacu pada laporan laba rugi yang mengukur perubahan nilai bersih perusahaan. Berdasarkan hal diatas, dapat diambil suatu hipotesis yang mengacu pada earnings dan market venture.

$\mathrm{H}_{4}$ : Earnings Before Interest Tax berpengaruh signifikan negatif terhadap market venture

\section{Metode}

Populasi yang digunakan dalam penelitian ini adalah seluruh perusahaan manufaktur yang terdaftar (listing) di Bursa Efek Indonesia (BEI) pada tahun 2005-2014 serta dari situs resmi Bursa Efek Indonesia (http://www.idx.co.id) Variabel yang digunakan dalam penelitian ini adalah variabel dependen yang berupa Market venture. Sedangkan variabel independennya adalah degree of operating leverage, degree of financial leverage, dan degree of total leverage. Adapun definisi operasional dari variabel-variabel tersebut adalah sebagai berikut.

Tabel 2. Kriteria Sampel

\begin{tabular}{lll}
\hline No & Keterangan & Jumlah \\
\hline 1 & Perusahaan Manufaktur yang tercatat di BEI berturut selama 2005-2014 & 123 \\
2 & Perusahaan Manufaktur yang delisting & $(16)$ \\
3 & Perusahaan Manufaktur yang tidak menerbitkan laporan keuangan & 0 \\
& Jumlah & 107 \\
\hline
\end{tabular}

Tabel 3. Pengukuran Variabel Dependen (Y)

\begin{tabular}{lll}
\hline Variabel Dependen & Pengukuran & Rujukan \\
\hline Market venture & $\alpha+\beta_{\mathrm{i}} \mathrm{R}_{\mathrm{mt}}+\mathrm{e}_{\mathrm{it}}$ & (Houmes,dkk : 2012) \\
Return pasar & $(\mathrm{IHSGt}-\mathrm{IHSGt}-1) /(\mathrm{IHSGt}-1)$ & (Fidiana: 2009) \\
Return saham & $(\mathrm{Pi}$ t-Pi t-1)/(Pi t-1) & (Fidiana: 2009) \\
\hline
\end{tabular}

Tabel 4. Pengukuran Variabel Independen (X)

\begin{tabular}{lll}
\hline Variabel Independen & Pengukuran & Rujukan \\
\hline Degree of Operating Leverage & $(\triangle \mathrm{EBIT} / \mathrm{EBIT}) /(\triangle \mathrm{S} / \mathrm{S})$ & (Chiou dan $\mathrm{Su}: 2007)$ \\
Degree of Financial Leverage & $(\triangle$ Earning/Earning $) /(\Delta \mathrm{EBIT} / \mathrm{EBIT})$ & (Chiou dan $\mathrm{Su}: 2007)$ \\
Degree of Total Leverage & $D O L^{*} D F L$ & (Chiou dan $\mathrm{Su}: 2007)$ \\
EBIT(Earning) growth & Presentase perubahan EBIT & (Hwa Lee dan Wooi Hooy : 2012) \\
\hline
\end{tabular}


Pengujian dilakukan dengan uji data panel dengan teknik radom effect. Uji random effect uji t memliki penentuan hipotesis sebagai berikut:

- Jika p-value < alpha 0,10 maka H0 di terima

- Jika p-value $\geq$ alpha 0,10 maka H0 ditolak

\section{Hasil Penelitian dan Pembahasan}

Berdasarkan hasil pengujian selama 10 tahun pengamatan, market venture dapat disimpulkan tahun yang memiliki variasi yang sangat tinggi, yaitu tahun 2005, dan 2010. Degree of operating leverage setiap tahun memiliki variasi yang sangat tinggi. Degree of financial leverage memiliki variasi yang sangat tinggi, yaitu tahun 2005, 2007, 2008, 2009, 2011, dan 2014. Degree of total leverage setiap tahun memiliki variasi yang sangat tinggi. Earning setiap tahun memiliki variasi yang sangat tinggi. Hal ini dikarenakan standar deviasi memiliki hasil dua kali lebih tinggi dari mean sehingga keadaan ini membuat sangat bervariasi dan memiliki outliers. (tabel.5)

Koefisien determinasi $\left(\mathrm{R}^{2}\right)$ pada intinya mengukur seberapa jauh kemampuan model dalam menerangkan variasi variable dependen. Nilai yang mendekati satu berarti variabelvariabel independen memberikan hampir semua informasi yang dibutuhkan untuk memprediksi variasi variable dependen. Berdasarkan hasil dibawah ini, Adjusted $\mathrm{R}^{2}$ yaitu 1.000. Serta, probability F (Prob(F-statistic)) pada output adalah 0,000 . Hal ini memaknai bahwa variabel independen secara bersama-sama dan signifikan mempengaruhi variabel dependen. Uji t-statistik dipergunakan untuk membuktikan hipotesis $\left(\mathrm{H}_{1}, \mathrm{H}_{2}, \mathrm{H}_{3}, \mathrm{H}_{4}\right.$ dan $\left.\mathrm{H}_{5}\right)$ dengan random effect dikarnakan penelitian ini memuat antar waktu dan antar individu. Berikut output hasil dari random effect: (tabel.6)

Tabel 5. Deskripsi Market Venture

\begin{tabular}{|c|c|c|c|c|c|c|c|c|c|c|}
\hline \multirow{2}{*}{ Tahun } & \multicolumn{2}{|c|}{ Market Venture } & \multicolumn{2}{|c|}{$\begin{array}{l}\text { Degree of } \\
\text { Operating } \\
\text { Leverage }\end{array}$} & \multicolumn{2}{|c|}{$\begin{array}{c}\text { Degree of } \\
\text { Fiamcial Leverage }\end{array}$} & \multicolumn{2}{|c|}{$\begin{array}{c}\text { Degree of Total } \\
\text { Leverage }\end{array}$} & \multicolumn{2}{|c|}{ Earnings } \\
\hline & Mean & $\begin{array}{l}\text { Std. } \\
\text { deviasi }\end{array}$ & Mean & $\begin{array}{l}\text { Std. } \\
\text { deviasi }\end{array}$ & Mean & $\begin{array}{l}\text { Std. } \\
\text { deviasi }\end{array}$ & Mean & $\begin{array}{l}\text { Std. } \\
\text { deviasi }\end{array}$ & Mean & $\begin{array}{l}\text { Std. } \\
\text { deviasi }\end{array}$ \\
\hline 2005 & 0,13 & 0,51 & $-0,23$ & 28,92 & $-2,91$ & 28,83 & $-13,26$ & 154,74 & 0,35 & 1,76 \\
\hline 2006 & $-0,36$ & 0,45 & 79,47 & 1092,96 & 0,92 & 1,47 & $-19,34$ & 207,02 & $-1,64$ & 19,4 \\
\hline 2007 & $-0,36$ & 0,38 & $-7,22$ & 84,82 & 8,34 & 76,86 & 1,11 & 71,7 & 1,37 & 17,96 \\
\hline 2008 & $-0,35$ & 0,44 & $-11,9$ & 105,14 & 1,26 & 4,95 & $-4,39$ & 113,02 & $-1,67$ & 18,92 \\
\hline 2009 & $-0,28$ & 0,36 & 40,25 & 245,16 & 0,56 & 7,62 & 21,76 & 193,05 & 0,04 & 6,18 \\
\hline 2010 & 0,1 & 0,28 & 8,63 & 36,5 & 1,19 & 1,52 & 6,47 & 34,84 & $-0,34$ & 2,75 \\
\hline 2011 & $-0,25$ & 0,75 & 1,06 & 9,67 & 0,86 & 3,74 & 8,79 & 59,11 & $-0,56$ & 2,96 \\
\hline 2012 & $-0,22$ & 0,62 & 3,58 & 31,31 & 1,27 & 2,18 & 3,7 & 40,13 & 0,07 & 2,12 \\
\hline 2013 & $-0,31$ & 0,81 & $-9,52$ & 91,35 & 1,16 & 1,2 & $-5,07$ & 52,12 & 2,07 & 19,85 \\
\hline 2014 & $-0,21$ & 0,51 & $-0,41$ & 36,66 & 1,14 & 5,58 & $-4,25$ & 47,77 & 0,28 & 2,11 \\
\hline
\end{tabular}


Tabel 6. Hasil uji t random effect seluruhnya

\begin{tabular}{crrrl}
\hline Variable & Coefficient & \multicolumn{1}{c}{ Std. Error } & \multicolumn{1}{c}{ t-Statistic } & Prob. \\
\hline C & 2.009 .455 & 0.099102 & 20276.61 & 0.0000 \\
DOL? & -0.224419 & 0.163962 & -1.368 .727 & 0.1714 \\
DFL? & -0.000308 & 0.000268 & -1.151 .298 & 0.2499 \\
DTL? & 0.000292 & 0.003526 & 0.082891 & 0.9340 \\
EARNING? & 0.001032 & 0.000830 & 1.243 .740 & 0.2139 \\
R-squared & & 1.000 .000 & & \\
Adjusted R-squared & 1.000 .000 & & \\
S.E. of regression & $3.46 \mathrm{E}-11$ & & \\
F-statistic & $1.50 \mathrm{E}+23$ & & \\
Prob(F-statistic) & 0.000000 & & \\
\hline
\end{tabular}

Tabel 7. Hasil uji t Random Effect Secara Per Tahun

\begin{tabular}{rrrrrrrrr}
\hline \multirow{2}{*}{ Tahun } & \multicolumn{2}{c}{$\begin{array}{c}\text { Degree of Operating } \\
\text { Leverage }\end{array}$} & \multicolumn{2}{c}{$\begin{array}{c}\text { Degree of Fiamcial } \\
\text { Leverage }\end{array}$} & \multicolumn{2}{c}{$\begin{array}{c}\text { Degree of Total } \\
\text { Leverage }\end{array}$} & \multicolumn{2}{c}{ Earnings } \\
\cline { 2 - 9 } & Sign & Keterangan & Sign & Keterangan & Sign & Keterangan & Sign & Keterangan \\
\hline 2005 & - & Signifikan & - & Signifikan & + & Signifikan & + & Signifikan \\
2006 & + & Signifikan & - & Signifikan & - & Signifikan & + & Signifikan \\
2007 & + & Signifikan & + & Signifikan & - & Signifikan & - & Tdk \\
2008 & + & Signifikan & + & Signifikan & - & Signifikan & - & Signifikan \\
2009 & + & Signifikan & - & Signifikan & - & Tdk Signifikan & + & Signifikan \\
2010 & - & Signifikan & - & Signifikan & - & Signifikan & + & Signifikan \\
2011 & + & Signifikan & - & Signifikan & - & Signifikan & - & Signifikan \\
2012 & + & Signifikan & + & Signifikan & - & Signifikan & - & Signifikan \\
2013 & + & Signifikan & - & Signifikan & - & Signifikan & + & Signifikan \\
2014 & + & Signifikan & - & Signifikan & - & Signifikan & - & Tdk \\
\hline
\end{tabular}

Degree of Operating Leverage dan Market Venture

Degree of operating leverage atau DOL dapat terjadi dari tindakan sampai sejauh mana biaya tetap dapat digunakan dalam operasi suatu perusahaan sehingga sebagian besar dari total biaya merupakan biaya tetap, maka perusahaan tersebut dikatakan memiliki tingkat leverage operasi. Tingkat degree of operating leverage yang tinggi akan memperbesar marke venture saat investasi. Market venture susah dihindari dari investasi di pasar modal. Hal ini dikarenakan melekatnya return index harga saham gabungan dan return saham. Berikut pergerakan degree of operating leverage dengan market venture.

Berdasarkan gambar 2, tahun 2005 terlihat pergerakan degree of operating leverage yang mulai naik yang secara normal akan mempengaruhi tingginya market venture akan tetapi dalam hal ini degree of operating leverage yang tinggi memperkecil market venture dan hal ini menghasilkan signifikan negatif dikarenakan keadaan perusahaan yang mampu menangani pinjaman operasional dengan menghasilkan pendapatan yang lebih dari pinjaman operasional. 


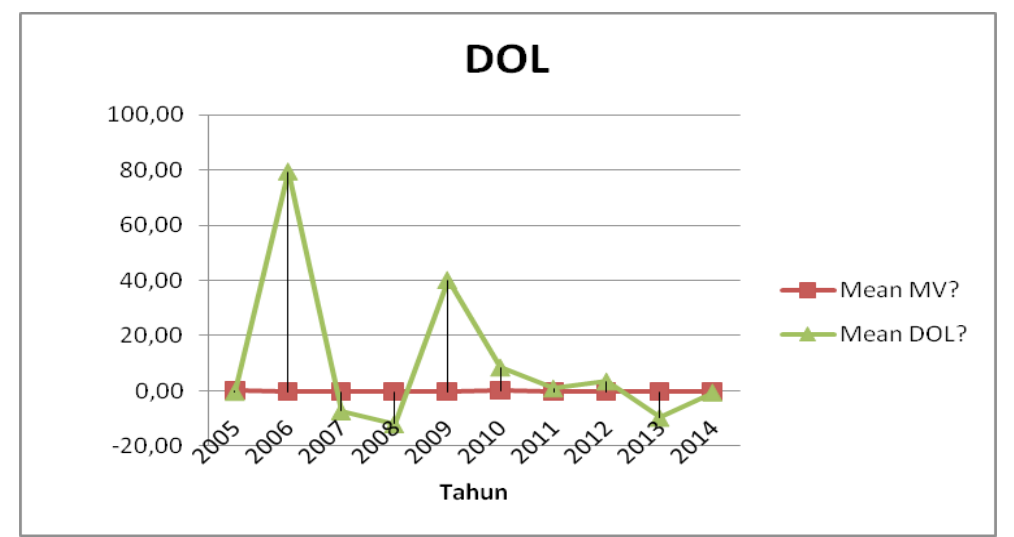

Gambar 2. Pergerakan Market Venture dengan Degree of Opeating Leverage

Pada gambar diatas, pada tahun 2006 grafik naik dan signifikan positif dikarenakan meningkatnya biaya tetap operasional perusahaan untuk mengoptimalkan kegiatan produksi perusahaan akan tetapi peningkatan biaya tetap untuk produksi tidak menghasilkan hal yang menguntungkan sehingga meningkatkan market venture. Penurunan pada tahun 2008 dikarenakan terjadi krisis global yang berdampak di Indonesia sehingga pengguaan biaya tetap untuk operasional perusahaan mengalami penurunan sehingga market venture perusahaan pun menurun.

Pada tahun 2010 grafik degree of operating leverage mengalami penurunan akan tetapi menghasilkan signifikan negatif dalam hal ini perusahaan sudah melakukan pengurangan biaya tetap akan tetapi tidak mampu menaikkan pendapatan perusahaan sehingga tingkat pengembalian untuk investor akan mengalami gangguan. Dengan begitu, perusahaan memiliki market venture yang tinggi.

\section{Degree of Financial Leverage dan Market Venture}

Degree of financial leverage ditimbulkan dari penggunaan sumber dana perusahaan dari hutang yang menyebabkan perusahaan harus menanggung beban atas penggunaan hutang setiap tahunnya. Pada umumnya, pendanaan menggunakan hutang akan menigkatkan tingkat pengembalian suatu investasi, tetapi hutang juga meningkatkan market venture para pemilik perusahaan, yaitu pemegang saham biasa. Market venture berkaitan dengan perubahan yang terjadi di pasar secara keseluruhan. Perubahan pasar tersebut akan mempengaruhi return suatu investasi. Berikut pergerakan degree of financial leverage dengan market venture.

Berdasarkan gambar 3, tahun 2005, 2009, 2011, 2013, dan 2014 terjadi penurunan grafik dan signifikan negatif dikarenakan penurunan pinjaman keuangan sehingga akan berkurangnya modal perusahaan untuk membayar tingkat

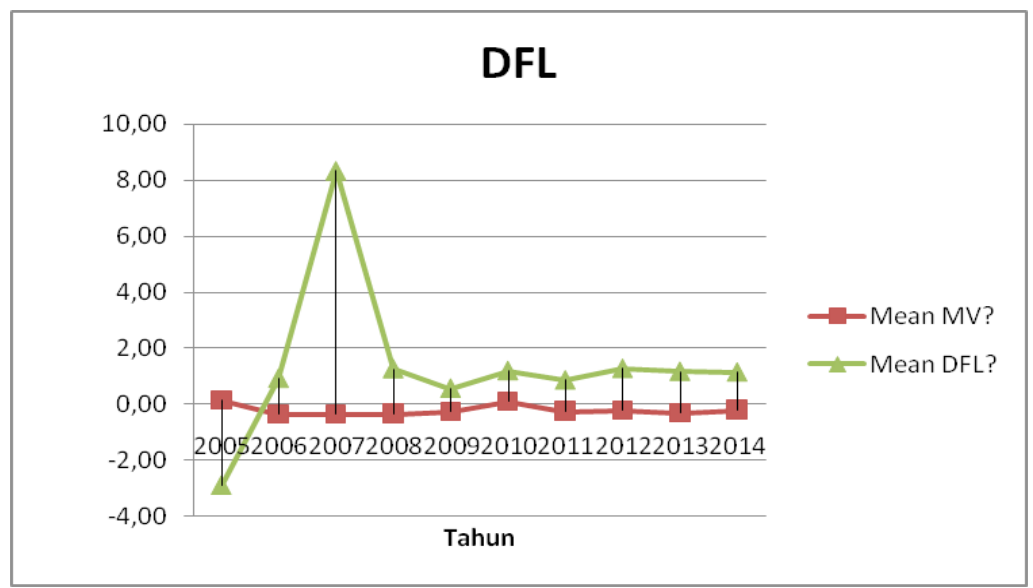

Gambar 3. Pergerakan Market Venture dengan Degree of Financial Leverage 
pengembalian investor. Pada tahun 2006 dan 2010 grafik naik dan signifikan negatif dikarenakan perusahaan melakukan pinjaman keuangan yang tinggi dan dapat mengoptimalisasikan hasil yang lebih besar dari pinjaman sehingga market venture yang diperoleh investor berkurang.

Pada tahun 2007 mengalami grafik peningkatan dan signifikan positif hal ini dikarenakan perusahaan mengambil keputusan untuk penggunaan dana dari pinjaman untuk meningkatkan penjualan akan tetapi ketidak mampuan pendapatan yang diperoleh untuk menutupi penggunaan dana dari pinjaman sehingga meningkatkan market venture.

\section{Degree of Total Leverage dan Market Venture}

Degree of total leverage merupakan kombinasi perhitungan dari operating leverage dan financial leverage. Pergerakan degree of operating leverage dan degree of financial leverage akan mempengaruhi pergerakan degree of total leverage. Market veture sebagai bagian dari risiko pasar sangat tergantung pada investor dalam mendefinisikan kondisi pasar dan ini berpengaruh dalam perubahan harga saham yang umumnya dikaitkan dengan perubahan dalam pengharapan investor terhadap prospek perusahaan. Untuk mengetahui kondisi pasar dipergunakan indeks pasar sebagai indikator keadaana pasar modal di Indonesia yang dalam penelitian ini diwakili oleh IHSG. Berikut pergerakan degree of total leverage dengan market venture.
Berdasarkan gambar 4, pergerakan tahun 2005 terjadi turun dan signifikan positif terhadap market venture dikarenakan bencana alam yang terjadi mengakibatkan perusahaan untuk mengurangi biaya tetap operasional dan keuangan dan keadaan ini mengakibatkan market venture menurun dikarenakan laba yang dihasilkan tahun lalu mampu untuk membantu kegiatan perusahaan. Sedangkan pada tahun 2009, grafik bergerak naik dan tidak signifikan hal ini dikarenakan dikarenakan pihak investor menanamkan investasinya tidak berdasarkan tinggi rendahnya operasional dan hutang pendanaan perusahaan dalam struktur modal.

Selain itu, pada tahun 2006, 2008, 2010, 2012, 2013, dan 2014 terjadi signifikan negatif dan penurunan grafik disebabkan penurunan biaya tetap operasional dan biaya tetap keuangan yang akan mengurangi biaya pendanaan untuk operasional perusahaan dan tidak optimalnya hasil produksi perusahaan sehingga pendapatan perusahaan akan berkurang dan berdampak meningkatnya market venture yang didapat investor. Sedangkan pada tahun 2007 dan 2011, peningkatan grafik dan signifikan negatif dikarenakan terjadinya peningkatan biaya tetap operasional dan keuangan perusahaan akan tetapi perusahaan mampu menghasilkan pendapatan yang optimal sehingga menghasikan pengurangan market venture yang didapat investor.

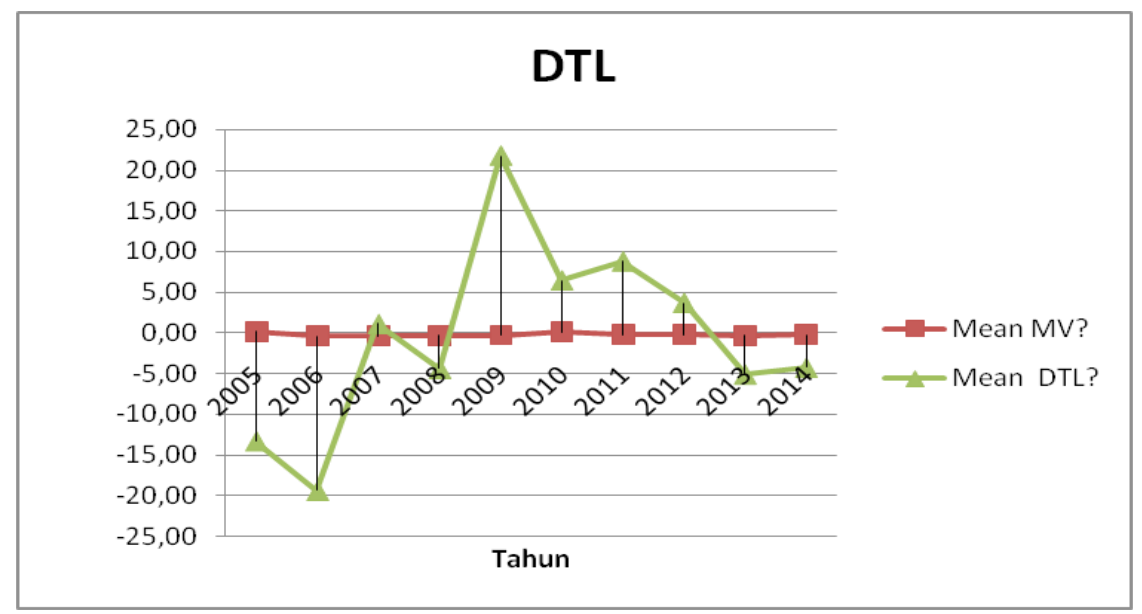

Gambar 4. Pergerakan Market Venture dengan Degree of Total Leverage 


\section{Earning dan Market Venture}

Earnings before interest and tax merupakan hasil dari kegiatan perusahaan. Earning before interest and tax merupakan pendapatan operasi untuk satu periode akuntansi dikurangi seluruh biaya operasi, yang mencakup harga pokok produksi. Market venture ini merupakan perbedaan antara return aktual yang diterima dengan return yang diharapkan. Semakin besar kemungkinan perbedaannya, maka akan semakin besar risiko investasi tersebut. Berikut pergerakan earnings before interest and tax dengan market venture.

Berdasarkan gambar 5, pada tahun 2005, 2006, dan 2010 terjadi penurunan grafik pada earning before interest tax akan tetapi berpengaruh signifikan positif terhadap market venture hal ini dikarenakan earning before interest tax yang dihasilkan tidak didanai oleh hutang sehingga market venture menurun. Di tahun selanjutnya yaitu 2007, pergerakan grafik meningkat akan tetapi tidak signifikan dikarenakan investor tidak melakukan investasi berdasarkan hasil earning before interest tax perusahaan.

Sedangkan pada tahun 2013 earning before interest tax mengalami peningkatan akan tetapi signifikan positif hal ini disebabkan oleh operasional perusahaan didanai sebagian besar oleh hutang dan perusahaan akan memakai earning before interest tax untuk membayar hutang sehingga investor memiliki market venture yang tinggi. Sedangkan pada tahun 2014, grafik pun kembali menurun dan tidak signifikan dikarenakan investor melakukan investasi tidak berdasarkan hasil kinerja perusahaan dan perusahaan tidak mampu menghasilkan earning before interest tax yang optimal dari kegiatan usahanya.

\section{Simpulan, Keterbatasan, dan Implikasi Hasil Penelitian}

Dari hasil pengujian yang dilakukan dengan model regresi data panel terhadap 107 perusahaan manufaktur untuk periode 2005 - 2014, dapat disimpulkan sebagai berikut, bahwa secara keseluruhan degree of operating leverage, degree of financial leverage, degree of total leverage, dan earnings before interest tax tidak berpengaruh terhadap market venture. Hasil pengujian berdasarkan tahun menunjukkan bahwa, degree of operating leverage pada tahun 2005 terjadi tingkat hutang yang tinggi untuk kebutuhan operasional menghasilkan laba yang dapat menutupi lebih besar dari hutang sehingga market venture dapat diperkecil. Saat tahun 2006, 2007, 2008, 2009, 2011, 2012, 2013, dan 2014 terjadi degree of operating leverage meningkat yang akan mempengaruhi meningkatnya market vernture. Sedangkantahun2010terjadiperusahaan melakukan pengurangan pada operasional perusahaan tidak mampu memaksimalkan hasil sehingga investor memiliki market venture dikarenakan tingkat pengembalian tidak terjadi.

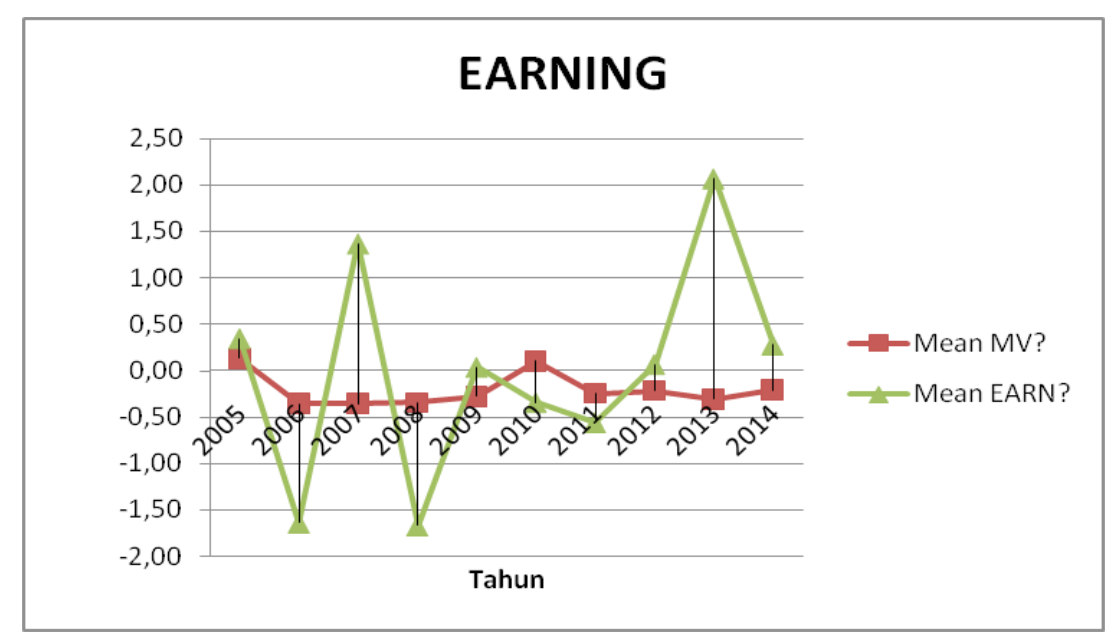

Gambar 3. Pergerakan Market Venture dengan Earning 
Degree of financial leverage pada tahun 2005, 2009, 2011, 2013, dan 2014 terjadi penurunan pinjaman keuangan sehingga modal dalam perusahaan berkurang dan menyebabkan terjadi hasil yang tidak optimal maka akan meningkatkan market venture. Saat tahun 2006 dan 2010 terjadi hasil yang dikelola perusahaan dapat secara optimal untuk mengurangi kewajiban perusahaan sehingga market venture menurun dan tahun 2007, 2008 dan 2012 terjadi degree of financial leverage meningkat sehingga akan meningkatkan market venture.

Degree of total leverage pada tahun 2005 terjadi bencana alam yang terjadi mengakibatkan perusahaan untuk mengurangi biaya tetap operasional dan keuangan dan keadaan ini mengakibatkan market venture menurun dikarenakan laba yang dihasilkan tahun lalu mampu untuk membantu kegiatan perusahaan. Saat tahun 2009 terjadi pihak investor menanamkan investasinya tidak berdasarkan tinggi rendahnya operasional dan hutang pendanaan perusahaan dalam struktur modal. Sedangkan tahun 2006, 2008, 2010, 2012, 2013, dan 2014 terjadi penurunan biaya tetap operasional dan biaya tetap keuangan yang akan mengurangi biaya pendanaan untuk operasional perusahaan dan tidak optimalnya hasil produksi perusahaan sehingga pendapatan perusahaan akan berkurang dan berdampak meningkatnya market venture yang didapat investor. Serta tahun 2007 dan 2011 terjadinya peningkatan biaya tetap operasional dan keuangan perusahaan akan tetapi perusahaan mampu menghasilkan pendapatan yang optimal sehingga menghasikan pengurangan market venture yang didapat investor.

Earnings before interest tax pada tahun 2005, 2006, dan 2010 terjadi penurunan earning before interest tax yang dihasilkan tidak didanai oleh hutang sehingga market venture menurun. Saat tahun 2007 terjadi investor tidak melakukan investasi berdasarkan hasil earning before interest tax perusahaan dan tahun 2013 terjadi operasional perusahaan didanai sebagian besar oleh hutang dan perusahaan akan memakai earning before interest tax untuk membayar hutang sehingga investor memiliki market venture yang tinggi.
Serta tahun 2014 terjadi dikarenakan investor melakukan investasi tidak berdasarkan hasil kinerja perusahaan dan perusahaan tidak mampu menghasilkan earning before interest tax yang optimal dari kegiatan usahanya.

Penelitian ini diharapkan berkontribusi terhadap penelitian lebih lanjut mengenai market venture. Ada pun keterbatasan penelitian sebagai berikut:

1. Kelebihan penelitian ini adalah model regresi panel menyediakan data yang lebih banyak dan informasi yang lebih lengkap serta bervariasi.

2. Adapun kelemahan penelitian ini antara lain hanya mencakup degree of operating leverage, degree offinancial leverage, degree of total leverage dan earnings.

Saran bagi peneliti selanjutnya, yaitu, peneliti selanjutnya meneliti variabel-variabel kualitas laba, good cooperate governance, dan opini audit untuk mengetahui hal yang mempengaruhi market venture. Hasil penelitian ini dapat sebagai rujukan atau dasar untuk merencanakan meningkatkan investasi dengan penilaian market venture. Adapun saran selain diatas dapat dipergunakan untuk pihak-pihak, sebagai berikut, pihak internal perusahaan, sebagai pengetahuan informasi mengenai degree of operating leverage, degree of financial leverage, degree of total leverage dan earning bagi keputusan investasi di pasar modal. Pihak pemerintah, sebagai pemberi informasi market venture kepada investor dengan cara membangun instansi dan pencatatan market venture lebih baik.

\section{Daftar Rujukan}

Akbari, Peyman dan Mohammadi Ehsan. 2013. A Study of the Effects of Leverages Ratio on Systematic Risk based on the Capital Asset Pricing Model Among Accepted Companies in Tehran Stock Market. Journal of Educational and Management Studies J. Educ. Manage. Stud Vol. 34.

Alaghi, Kheder. 2011. Financial leverage and systematic risk. African Journal of Business Management Vol. 515. 
Al-Qaisi, Khaldoun M. 2011. The Economic Determinants of Systematic Risk in the Jordanian Capital Market. International Journal of Business and Social Science Vol. 2 No. 20.

Amorim, Ana Luísa Gambi Cavallari, dkk. 2012. Analysis of the Relationship between Accounting Information and Systematic Risk in the Brazilian Market. R. Cont. Fin. - USP, São Paulo, vol 23, no 60.

Bebeşelea, M. 2014. Accounting information and its users. A study of the supply and demand of accounting information in Romania. Economics, Management, and Financial Markets, 4.

Brealey, Myers, Marcus. 2007. Dasar-dasar Manajemen Keuangan Perusahaan. Jakarta: Erlangga.

Brigham, Eugene F dan Joel F. Houston. 2011. Dasar-Dasar Manajemen Keuangan. Edisi 11 Buku 2. Jakarta: Salemba Empat.

Ebrahimpour, Hamid, dkk. 2013. The Relationship between Disclosure of Market Risk and Accounting Measures of Risk: Evidence from the Tehran Stock Exchange. World of Sciences Journal.

Fidiana. 2009. Nilai-nilai Fundamentak dan Pengaruhnya Terhadap Beta Saham Syariah Pada JII, Ekuitas Vol. 13 No. 1.

Gheorghe, Dumitru. 2012. The Accounting Information Quality Concept. Economics, Management, and Financial Markets Volume 74.

Ghozali, Imam, 2006. Aplikai Analisis Multivarite dengan SPSS, Cetakan Keempat, Badan Penerbit Universitas Diponegoro, Semarang.

Hartono, Jogiyanto. 2010. Teori Portofolio dan Analisis Investasi. Edisi Ketujuh. Yogyakarta: $B P F E$.

Houmes, Robert E, dkk. 2012. The operating leverage impact on systematic risk within a context of choice An analysis of the US trucking industry. Managerial Finance Vol. 38 No. 12.

Hamidah, dan Fajar Subhan. 2015. DER, DOL, EPS, Ukuran Perusahaan dan Risiko
Sistematis Saham Perusahaan Pertambangan di Bursa Efek Indonesia 2009-2012. Kalbisocio, Vol 2 No 1.

Jarvela, dkk. 2009. The Relationship Between Market and Accounting Determined Risk Measures: Reviewing And Updating The Beaver, Kettler, Scholes 1970 Study. College Teaching Methods \& Styles Journal - Special Edition.

Jen Li, Rong dan Glenn V Henderson,Jr. 1991. Combined Leverage and Stock Risk on systematic risk within a context of choice An analysis of the US trucking industry. Quarterly Journal of Business and Economic Vol 30 no 1.

Kartikasari, Lisa. 2007. Pengaruh Variabel Fundamental Terhadap Risiko Sistematik Pada Perusahaan Manufaktur yang Terdaftar di BEJ. Jurnal Akuntansi dan Manajemen Vol XVIII No. 1.

Koussis, Nicos dan Michalis Makrominas. 2015. Growth options, option exercise and firms' systematic risk. Rev Quant Finan Acc.

Lee, Chyn-Hwa dan Chee-Wooi Hooy. 2012. Determinants of systematic financial risk exposures of airlines in North America, Europe and Asia. Journal of Air Transport Management.

Lee, Soin dan Sang-Bum Park. 2014. A Study on the Association between Operating Leverage and Risk: The Case of the Airline Industry. International Journal of Economics and Finance; Vol. 6, No. 3.

Musavi, Seyed Habib dan Iman Zare. 2013. Relation between DOL, DFL and DTL with systematic risk. Life Science Journal Vol 10.

Ohlson, James A. 1995. Earnings, Book Values, and Dividends in Equity Valuation. Contemporary Accounting Research Vol.11 No.2.

Ratna, Anggi Mashita dan Maswar Patuh Priyadi. 2014. Pengaruh Faktor Fundamental dan Variabel Makro Ekonomi Terhadap Beta Saham Syariah. Jurnal Ilmu dan Riset Akuntansi. Vol. 3, No. 7

Salama, Aly dan Duc Tuan Nguyen. 2005. The Association between Accounting and Market- 
Based Risk Measures. Working Paper.

Sarwono, Jonathan. 2016. Prosedur Analisis Populer Aplikasi Riset Skripsi dan Tesis dengan Eviews, Cetakan Kesatu, Penerbit Gava Media, Yogyakarta.

Sarwono, Jonathan dan Hendra. 2014. Cara Operasi dan Prosedur Analisis, Edisi Kesatu, Penerbit ANDI, Yogyakarta.

Savitri, Enni dan Andra Lolija Pramudya. 2012. Pengaruh Ratio Leverage terhadap Risiko Pasar Pada Perusahaan Manufaktur di Bursa Efek Indonesia, Jurnal Akuntansi, Vol. 1, No. 1 ,

Su, Robert K dan Chei-Chang Chiou. 2007. On the relation of systematic risk and accounting variables. Managerial Finance Vol.33 No.8.

Toms, Steven, dkk. 2005. The Association between Accounting and Market-Based Risk Measures. Working Paper 15 December 2005.

Theriou, Nikolaos G, dkk. 2010. Testing the relation between beta and returns in the Athens stock exchange. Managerial Finance Vol. 36 No. 12.

Zare, Iman dan Jafar Nekounam. 2012. Study of relation between acounting information with market venture: case study of Iran stock exchange. African Journal of Business Management Vol 61. 